\title{
The prevalence of freezing of gait in Parkinson's disease and in patients with different disease durations and severities
}

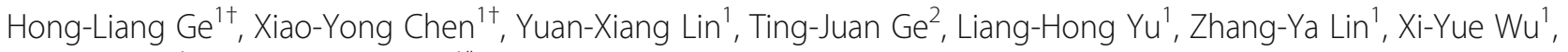
De-Zhi Kang ${ }^{1}$ and Chen-Yu Ding ${ }^{1 *}$

\begin{abstract}
Background: The prevalence rates of freezing of gait (FOG) in Parkinson's disease (PD) vary widely, ranging from 14.0 to $55.1 \%$. Our aim is to calculate the overall prevalence of FOG in all PD patients with different disease durations and severities.

Methods: Using Medline/PubMed/Embase, we carried out a systematic literature search for studies reporting the PD and clinically relevant FOG.

Results: After primary screening, a total of 35 studies were identified and further analyzed for inclusion into the analysis, and 29 studies fulfilled the quality criteria and included in this meta-analysis. The overall prevalence of FOG in PD was 39.9\% (95\% Cl 35.3-44.5\%). The FOG identified by the freezing of gait questionnaire item 3 may be more prevalent $(43.8 \%, 95 \% \mathrm{Cl} 38.5-49.1 \%)$ than the FOG identified by the Unified Parkinson's Disease Rating Scale item 14 (36.0\%, 95\% Cl 29.0-43.1\%). Disease duration and severity are both the clinical features associated with the FOG. The highest FOG prevalence rate in PD patients was seen in patients with disease durations $\geq 10$ years, at 70.8\%, followed that of PD patients with disease durations $\geq 5$ years (53.3\%), and PD patients with disease durations $<5$ years (22.4\%). FOG presented in 28.4\% of PD patients with Hoehn and Yahr staging (H\&Y) score $\leq 2.5$, and in $68.4 \%$ of PD patients with H\&Y score $\geq 2.5$.
\end{abstract}

Conclusion: This meta-analysis confirms that the prevalence of FOG in PD is considerable, and highlights the need for accurate identification of FOG in PD.

Keywords: Prevalence, Freezing, Gait, Parkinson disease

\section{Background}

Parkinson's disease (PD) is a neurodegenerative disease primarily characterized by rigidity, bradykinesia, and resting tremor; however, the freezing of gait (FOG) is also a common and disabling symptom in PD [1-3].

\footnotetext{
* Correspondence: dingcydr@163.com

${ }^{+}$Hong-Liang Ge and Xiao-Yong Chen contributed equally to this work and should be considered co-first authors.

'Department of Neurosurgery, The First Affiliated Hospital of Fujian Medical University, No. 20 Chazhong Road, Fuzhou 350004, Fujian Province, People's Republic of China

Full list of author information is available at the end of the article
}

FOG is characterized by sudden and brief episodes of inability to produce effective forward stepping [4-6]. Therefore, FOG proposes major risks for falls, and leading to disability to patients, making the efficient identification of it important [7].

Although FOG is common in PD, it has not been extensively studied. The prevalence of FOG in PD patients that are reported in the literature vary widely, ranging from 14.0 to $55.1 \%[8,9]$. Up to $86.5 \%$ of advanced PD patients experience FOG [10], and up to $37.8 \%$ of early PD patients have the FOG as defined by a validated scale

(c) The Author(s). 2020 Open Access This article is licensed under a Creative Commons Attribution 4.0 International License, which permits use, sharing, adaptation, distribution and reproduction in any medium or format, as long as you give appropriate credit to the original author(s) and the source, provide a link to the Creative Commons licence, and indicate if changes were made. The images or other third party material in this article are included in the article's Creative Commons licence, unless indicated otherwise in a credit line to the material. If material is not included in the article's Creative Commons licence and your intended use is not permitted by statutory regulation or exceeds the permitted use, you will need to obtain permission directly from the copyright holder. To view a copy of this licence, visit http://creativecommons.org/licenses/by/4.0/ The Creative Commons Public Domain Dedication waiver (http://creativecommons.org/publicdomain/zero/1.0/) applies to the data made available in this article, unless otherwise stated in a credit line to the data. 
[11]. The different rates reported could be caused by the way the FOG is diagnosed, the nature of the PD patients being studied, the date of study conducted, the quality of studies, and the geographical region. Given this background, the present meta-analysis aims to calculate the overall prevalence of FOG in all PD patients, and to calculate the FOG prevalences in PD patients with different disease durations and severities.

\section{Methods}

\section{Search strategy}

This meta-analysis was performed according to PRISMA guideline [12]. A systematic literature search was carried out using databases Medline/PubMed/Embase. The entire time scale was used up to April 23, 2019. To include all actual literature on FOG in PD, we used the following terms: "freezing" or "gait" or "frozen" or "FOG" in combination with "Parkinson". Pubmed was searched by text keywords and Medical Subject Heading terms. Embase was searched by Emtree and text words. Our results were limited to the humans and English language literature.

\section{Quality assessment}

The reliability of the literature was assessed with the modified quality assessment of diagnostic accuracy studies (QUADAS) tool, which is an efficient quality assessment system [13, 14] and was previously used to determine the prevalence of anxiety [15] and pain [16] in PD. Ten independent scores are included in the criteria used to evaluate the quality of the included studies using the modified QUADAS tool (Table 1). The score ranges from 0 to 19 points, with $>13$ points (corresponds to $75 \%$ of the highest score) being the cut-off level of methodological acceptability $[15,16]$. The studies were independently reviewed by 2 authors (HLG and $\mathrm{XYC}$ ). In case of discrepancies between the raters, a decision was made after reassessment by the corresponding authors (CYD).

\section{Data extraction and validity assessment}

Two authors (HLG and XYC) independently reviewed the full texts of the selected studies. Any disagreement between the two reviewers was resolved by the verdict of the corresponding authors (CYD). The interested variables included the clinical settings, prevalence rates of FOG, sample sizes, the scale used to diagnose the FOG, disease durations, and disease severities. The disease severity was measured by the Hoehn and Yahr staging ( $\mathrm{H} \& \mathrm{Y})$ scale. Higher score in $\mathrm{H} \& \mathrm{Y}$ corresponds to increased severity $[17,18]$. The diagnostic criteria of FOG varied across studies. Authors of different studies chose the diagnostic criteria of FOG based on their own
Table 1 Modified quality assessment of diagnostic accuracy studies tool: quality criteria for prevalence studies

\begin{tabular}{|c|c|c|}
\hline Sorts & Subsorts & Quality criteria \\
\hline \multirow[t]{13}{*}{ A } & & $\begin{array}{l}\text { The final sample should be representative of the target } \\
\text { population }\end{array}$ \\
\hline & \multirow[t]{4}{*}{1} & $\begin{array}{l}\text { At least } 1 \text { of the following should apply for the study } \\
\text { ( } 2 \text { points) }\end{array}$ \\
\hline & & - An entire target population \\
\hline & & - Randomly selected sample \\
\hline & & - Sample stated to represent the target population \\
\hline & \multirow[t]{5}{*}{2} & At least one of the following (2 points) \\
\hline & & - Reasons for nonresponders described \\
\hline & & - Nonresponders described \\
\hline & & - Comparison of responders and nonresponders \\
\hline & & - Comparison of sample and target population \\
\hline & \multirow[t]{3}{*}{3} & Response rate > 90\% (2 points) \\
\hline & & Response rate $70 \%$ to $90 \%$ (1 point) \\
\hline & & Response rate $\leq 70 \%$ (0 points) \\
\hline \multirow[t]{6}{*}{ B } & & Quality of data \\
\hline & 4 & $\begin{array}{l}\text { Were the data primary from a prevalence study ( } 2 \\
\text { points) or was it taken from a survey not specifically } \\
\text { designed for that purpose ( } 1 \text { point)? }\end{array}$ \\
\hline & 5 & $\begin{array}{l}\text { The same mode of data collection should be used for } \\
\text { all subjects ( } 2 \text { points), if not: } 1 \text { point }\end{array}$ \\
\hline & \multirow[t]{3}{*}{6} & $\begin{array}{l}\text { - The data have been collected directly from the } \\
\text { patient by means of a validated questionnaire/ } \\
\text { interview ( } 3 \text { points) }\end{array}$ \\
\hline & & $\begin{array}{l}\text { - No validated questionnaire/interview patients ( } 2 \\
\text { points) }\end{array}$ \\
\hline & & $\begin{array}{l}\text { - Data have been collected from proxies or } \\
\text { retrospectively from medical record ( } 1 \text { point). }\end{array}$ \\
\hline \multirow[t]{4}{*}{ C } & & $\begin{array}{l}\text { General description of the method and results should } \\
\text { include: }\end{array}$ \\
\hline & 7 & $\begin{array}{l}\text { Description of target population and setting where } \\
\text { patients were found ( } 2 \text { points) }\end{array}$ \\
\hline & 8 & $\begin{array}{l}\text { Description of stage of disease, sex, age (all } 2 \text { points, } 1 \\
\text { or 2: } 1 \text { point) }\end{array}$ \\
\hline & 9 & Final sample size (1 point) \\
\hline \multirow[t]{2}{*}{ D } & & Definition of FOG prevalence \\
\hline & 10 & Prevalence recall periods should be stated ( 1 point) \\
\hline
\end{tabular}

experiences. For this analysis, we followed the criteria stated by the authors of the selected studies.

\section{Heterogeneity and statistical analyses}

The statistical heterogeneity was calculated using the chi-square (Chi2) test at $10 \%$ significant level. If the value was $>50 \%$, a random-effect model was used. Otherwise, a fixed-effect model was adopted. The random-effects model should be used because these studies had a high heterogeneity $[19,20]$. Sub-group analysis and visual inspection of the data were 
performed to further investigate potential sources of heterogeneity. Chi-square test and hypothesis testing were used to compare the prevalence of objectively diagnosed FOG with subjectively diagnosed one. Considering the different statistical weights of the paper selected, we conducted a forest plot to solve this problem.

Meta-analysis was executed with STATA (version 12.0, Stata Corporation, College Station, TX, USA) to obtain the overall prevalence of FOG in PD. After estimating the overall FOG prevalence in PD patients, articles were first assessed for FOG prevalence based on the different diagnostic criteria then in PD patients with different disease duration, and lastly in PD patients with different disease severities.

\section{Results}

\section{Description of included studies}

We used the following terms: "freezing" or "gait" or "frozen" or "FOG" in combination with "Parkinson", which revealed 4500 articles after removing duplicates. Subsequently, the abstracts of these articles were read, reviews, and studies with only deep brain stimulation patients and unclear criteria for the diagnosis of FOG were excluded. All potential studies reporting the prevalence of FOG in PD patients were then read in full for eligibility and 188 articles were excluded for the following reasons: prevalence of FOG in PD was not mentioned $(n=94)$, there may be an insufficient description of a random or consecutive design of patient recruitment $(n=51)$, the publications stemmed from the same database or duplicate articles $(n=31)$, the population included had only neuroleptic-induced PD or PD with only dual-task difficulties $(n=4)$, or the full text was not found $(n=8)$. The remaining 35 studies were included in the qualitative analysis (Fig. 1).

Of the total of 35 studies included in the qualitative analyses, 16 focused on the FOG as a primary objective and the remaining studies reported FOG as a secondary outcome. Twenty-nine studies $(82.9 \%)$ were further analyzed as they met the cut-off score of 14 points on the QUADAS tool [8-11, 21-46]. All included studies were conducted after the year 2000, with approximately $72.4 \%$ of the articles published in the past 5 years, which likely reflects the increasing awareness in the past decade of FOG in PD.

Of the 29 studies meeting the quality criteria, 11 studies included patients from Europe, 8 from the USA, 4from Australia, 2 from China, and 4 from Israel. The overview of the studies included in this meta-analysis is illustrated in Table 2, and the prevalence of FOG reported in these studies is shown in Table 3.

A total of 22 studies included both early and advanced PD was used to calculate the overall estimated mean prevalence of FOG in all PD patients. Of these 22 studies, 13 reported FOG according to the freezing of gait questionnaire item 3 (FOG-Q item 3); 3 reported FOG according to the Unified Parkinson's Disease Rating Scale item 14 (UPDRS item 14); and 5 reported FOG according to other criteria ( 3 were self-reported); and 1 reported FOG according to FOG-Q item 3 or UPDRS item 14.

The remaining 7 studies included patients with the limitation in disease duration or disease severity. They were accepted in the supplemental analysis performed based on the disease durations and disease severities of PD patients.

\section{Prevalence of FOG}

Overall, 39.9\% (95\%CI 35.3-44.5\%) in a total of $5361 \mathrm{PD}$ patients experienced FOG. The FOG identified by the FOG-Q item 3 might be more prevalent $(43.8 \%$, 95\%CI $38.5-49.1 \%)$ than FOG identified by the UPDRS item 14 (36.0\%, 29.0-43.1\%) (Table 4, Fig. 2). In addition, the prevalence of FOG identified by objectively diagnostic criteria did not have a statistical difference with subjectively diagnosed one $(40.2 \%$, $95 \%$ CI $35.1-45.2 \%$ vs $38.4 \%$, 95\% CI 25.2-51.6\%, $P=0.442$ ) (Table 4).

For the prevalence rates of FOG in PD patients with different disease durations ( $0-5$ years, $\geq 5$ years, or $\geq 10$ years), FOG is most frequently seen in patients with disease duration $\geq 10$ years, at a prevalence rate of $70.8 \%$, followed by patients with disease duration $\geq 5$ years $(53.3 \%)$, and in patients with disease duration $<5$ years (22.4\%).

In terms of the level of severity, FOG presented in $28.4 \%$ of PD patients with $\mathrm{H} \& \mathrm{Y}$ score $\leq 2.5$, and in $68.4 \%$ of PD patients with H\&Y score $>2.5$ (Table 4).

Prevalence in recent studies $(2016-2019, n=11)$ was similar to older studies (2007-2015, $n=11)$. In addition, the prevalence in different regions was similar to each other (Table 5).

\section{Heterogeneity}

High heterogeneity was found among the synthesis results of included studies. Therefore, we performed subgroup analysis of the FOG prevalence in PD patients based on the scale used to diagnose the FOG, disease duration of PD, disease severity of PD, quality of included studies, date of study conducted, and geographical region. Nonetheless, the heterogeneity in almost all subgroups was considerable (Table 4, Table 5).

\section{Discussion}

\section{Reported prevalence and variation}

In this review, the prevalence of FOG in PD is reviewed for the first time. The results of this meta-analysis show that the overall prevalence of FOG in PD is $39.9 \%$. FOG is most frequently seen in PD patients with disease 


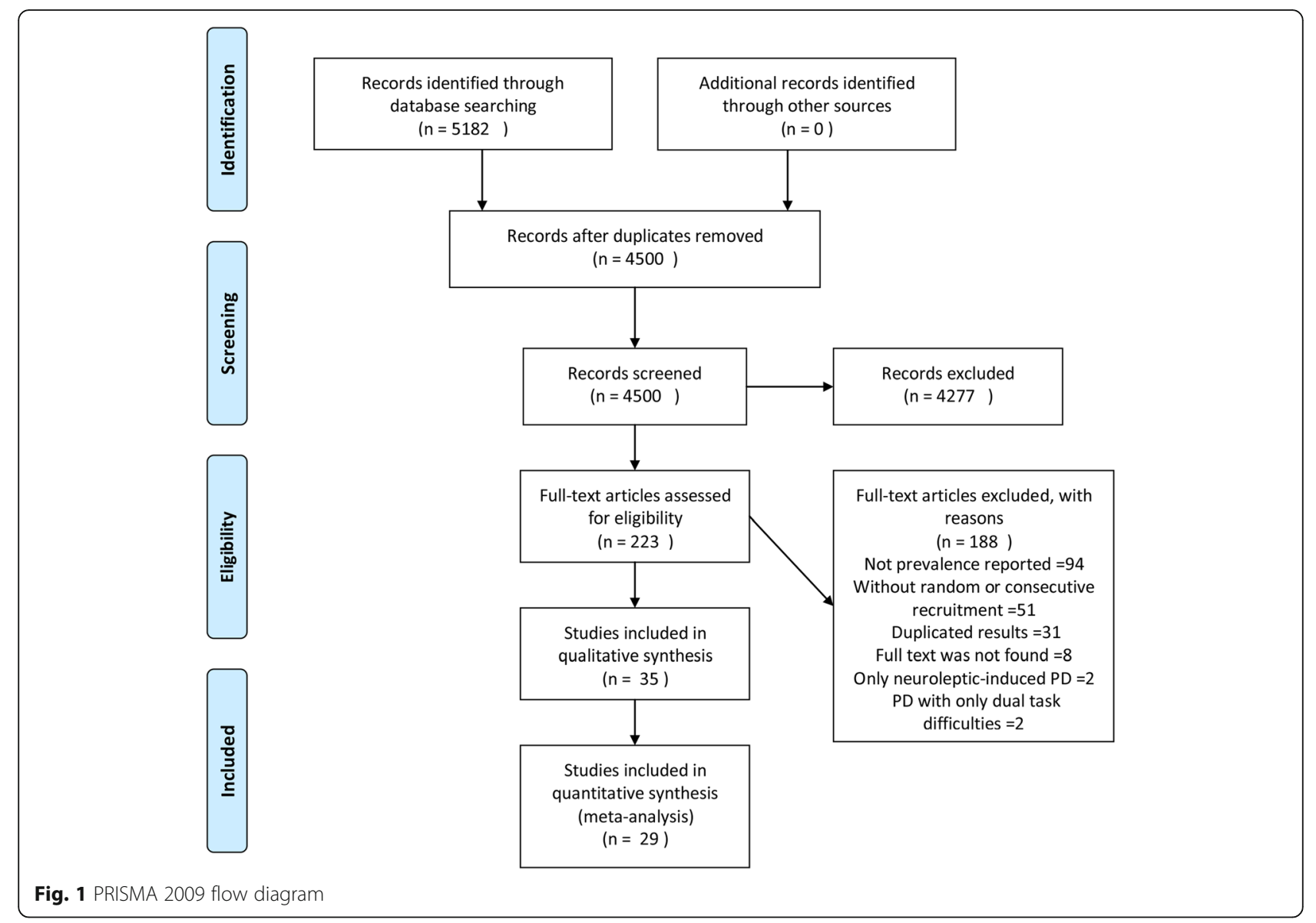

duration $\geq 10$ years at $70.8 \%$ (60.8-80.9\%), followed by PD patients with disease duration $\geq 5$ years $(53.3 \%$, $95 \%$ CI 45.8-60.8\%), and PD patients with disease duration < 5 years $(22.4 \%$, 95\% CI 12.8-31.9\%). In terms of severities, FOG was present in $28.4 \%$ (95\% CI 15.7-41.1\%) of PD patients with $\mathrm{H} \& \mathrm{Y}$ score $\leq 2.5$, and in $68.4 \%$ (95\% CI 58.7-78.2\%) of PD patients with $\mathrm{H} \& \mathrm{Y}$ score $>2.5$. Our results indicate that the prevalence of FOG in PD patients is considerable.

The prevalence of FOG identified by objectively diagnostic criteria did not have a statistical difference with subjectively diagnosed one $(40.2 \%, 95 \%$ CI $35.1-45.2 \%$ vs $38.4 \%, 95 \%$ CI $25.2-51.6 \%, p=0.442)$. However, the FOG identified by the FOG-Q item $3(43.8 \%, 95 \%$ CI 38.5-49.1\%) may be more prevalent than the FOG identified by the UPDRS item $14(36.0 \%, 29.0-43.1 \%)$. The item 3 of the FOG-Q, in comparison with item 14 of the UPDRS, identifies more PD patients as "freezers," which indicates that some patients might not report to have experienced FOG when evaluated with UPDRS item 14, but report to have experienced FOG when they are provided with a detailed explanation of what FOG is (FOGQ item 3) [47].
In this meta-analysis, it is confirmed that the FOG in $\mathrm{PD}$ is associated with increased severity $(\mathrm{H} \& \mathrm{Y})$ and longer disease duration. The disease severity $(H \& Y)$ and disease duration had been proven to be strong clinical features associated with FOG [11, 27, 28, 48]. In addition, the $\mathrm{H} \& \mathrm{Y}$ and disease duration may be attributed to the severity of FOG [49-51].

There is a wide range of the FOG prevalence reported in the included studies. The heterogeneity among the results of the included studies was not negligible. These studies were conducted in different regions, different diagnostic criteria of FOG were used, and patients with different durations and severities were included. These differences may be the sources of heterogeneity. However, $\mathrm{Chi}^{2}$ test was used in this study, which is highly effective in identifying small heterogeneities that might not be practically important [52]. In the sub-analysis, based on the scale used to diagnose FOG, disease duration, severity of PD, quality of included studies, date of study conducted, and geographical region, the heterogeneity was high. Furthermore, the dissimilarities of the medication states of FOG also contributed to the heterogeneity. The FOG prevalence rates vary in PD patients 
Table 2 Overview of the studies included in this meta-analysis

\begin{tabular}{|c|c|c|c|c|c|c|c|}
\hline Study & Country & $\begin{array}{l}\text { Sample } \\
\text { size }\end{array}$ & $\begin{array}{l}\text { Quality } \\
\text { score }\end{array}$ & $\begin{array}{l}\text { Identification of } \\
\text { FOG }\end{array}$ & Age (years) & Disease duration (years) & $H \& Y$ \\
\hline $\begin{array}{l}\text { Margolesky } \\
\text { et al [36] }\end{array}$ & $\begin{array}{l}\text { United } \\
\text { States }\end{array}$ & 102 & 19 & $\begin{array}{l}\text { freezing of gait was } \\
\text { self-reported }\end{array}$ & $68.0 \pm 10.0$ & $5.3 \pm 4.8$ & $1-4$ \\
\hline $\begin{array}{l}\text { Mckay et al } \\
{[46]}\end{array}$ & $\begin{array}{l}\text { United } \\
\text { States }\end{array}$ & 65 & 18 & $\begin{array}{l}\text { FOG-Q item } 3>1 \\
\text { or UPDRS item } 14> \\
1\end{array}$ & $68 \pm 10$ & $7.3 \pm 5.6$ & $1-3$ \\
\hline $\begin{array}{l}\text { Mancini } \\
\text { et al [40] }\end{array}$ & Israel & 94 & 16 & $\begin{array}{l}\text { new FOG-Q part I = } \\
\text { freezer }\end{array}$ & $\begin{array}{l}65.4 \pm 9.7 \text { for non-freezers; } 64.2 \pm \\
8.8 \text { for freezers }\end{array}$ & $\begin{array}{l}4.9 \pm 2.8 \text { for non-freezers; } 7.6 \pm \\
4.4 \text { for freezers }\end{array}$ & $\begin{array}{l}2.4 \pm 0.5 \text { for } \\
\text { non-freezers; } \\
3.2 \pm 0.8 \text { for }\end{array}$ \\
\hline $\begin{array}{l}\text { Djaldetti } \\
\text { et al [37] }\end{array}$ & Israel & 41 & 14 & UPDRS item 14 > 1 & $63.5 \pm 9.9$ & $9.5 \pm 3.2$ & $1-3$ \\
\hline $\begin{array}{l}\text { Ehgoetz } \\
\text { Martens } \\
\text { et al [38] }\end{array}$ & Australia & 221 & 15 & FOG-Q item $3 \geq 1$ & $\begin{array}{l}65.4 \pm 9.8 \text { for non-freezers; } 70.8 \pm \\
9.4 \text { for transitional freezers; } 70.2 \pm \\
10.9 \text { for continuing freezers }\end{array}$ & $\begin{array}{l}3.2 \pm 4.3 \text { for non-freezers; } 6.0 \pm \\
4.1 \text { for transitional freezers; } 9.7 \pm \\
7.5 \text { for continuing freezers }\end{array}$ & ND \\
\hline $\begin{array}{l}\text { Kader et al } \\
{[44]}\end{array}$ & Sweden & 243 & 16 & FOG-Q item $3 \geq 1$ & $70 \pm 9.2$ & $8(1-43)^{a}$ & $3(2-3)^{a}$ \\
\hline $\begin{array}{l}\text { Sutter et al } \\
{[45]}\end{array}$ & $\begin{array}{l}\text { United } \\
\text { States }\end{array}$ & 111 & 16 & $\begin{array}{l}\text { new FOG-Q item } 1 \\
>0\end{array}$ & $66.5 \pm 1.7$ & $4.0(2.0-8.0)^{\mathrm{a}}$ & $1-4$ \\
\hline $\begin{array}{l}\text { Forsyth } \\
\text { et al [43] }\end{array}$ & Australia & 82 & 16 & new FOG-Q & $66.5 \pm 7.6$ & $7.5 \pm 5.7$ & $2.0 \pm 0.7$ \\
\hline $\begin{array}{l}\text { Ricciardi } \\
\text { et al [41] }\end{array}$ & Italy & 43 & 15 & $\begin{array}{l}\text { new FOG-Q item } 1 \\
>0\end{array}$ & $68.0 \pm 11.6$ & $\begin{array}{l}5.3 \pm 5.4 \text { for non-freezers; } 9.5 \pm \\
5.8 \text { for freezers }\end{array}$ & ND \\
\hline $\begin{array}{l}\text { Vervoort } \\
\text { et al [42] }\end{array}$ & Belgium & 76 & 16 & $\begin{array}{l}\text { new FOG-Q or FOG } \\
\text { occurrence in the } \\
\text { lab }\end{array}$ & $60.6 \pm 10.0$ & $6.8 \pm 4.6$ & $2.1 \pm 0.5$ \\
\hline $\begin{array}{l}\text { Shin et al } \\
\text { [35] }\end{array}$ & $\begin{array}{l}\text { United } \\
\text { states }\end{array}$ & 141 & 14 & $\begin{array}{l}\text { freezing of gait was } \\
\text { self-reported }\end{array}$ & $69.7 \pm 8.21$ & $6.34 \pm 4.84$ & ND \\
\hline $\begin{array}{l}\text { Allen et al } \\
\text { [21] }\end{array}$ & Australia & 231 & 14 & $\begin{array}{l}\text { freezing of gait was } \\
\text { self-reported }\end{array}$ & $70.6 \pm 8.8$ & $7.9 \pm 5.9$ & ND \\
\hline $\begin{array}{l}\text { Amboni } \\
\text { et al [11] }\end{array}$ & Italy & 593 & 19 & FOG-Q item $3 \geq 1$ & $\begin{array}{l}66.1 \pm 9.7 \text { for non-freezers; } 67.5 \pm \\
8.7 \text { for freezers }\end{array}$ & $\begin{array}{l}6.1 \pm 3.8 \text { for non-freezers; } 9.8 \pm \\
4.8 \text { for freezers }\end{array}$ & $1-5$ \\
\hline $\begin{array}{l}\text { Forsaa et al } \\
\text { [22] }\end{array}$ & Norway & 232 & 17 & UPDRS item $14 \geq 1$ & $64.9(28.2-86.0)^{\mathrm{b}}$ & $8.6 \pm 5.7$ & $1-5$ \\
\hline $\begin{array}{l}\text { Gazibara } \\
\text { et al [23] }\end{array}$ & Serbia & 300 & 17 & $\begin{array}{l}\text { new FOG-Q item } 1 \\
>0\end{array}$ & $61.4(22-83)^{b}$ & $0.5-30$ & $1-4$ \\
\hline $\begin{array}{l}\text { Lieberman } \\
\text { et al }[24]\end{array}$ & $\begin{array}{l}\text { United } \\
\text { States }\end{array}$ & 212 & 14 & UPDRS item $14 \geq 2$ & ND & All patients $<5$ & $1-5$ \\
\hline $\begin{array}{l}\text { Lindholm } \\
\text { et al [25] }\end{array}$ & Sweden & 141 & 15 & FOG-Q item $3 \geq 1$ & $68 \pm 9.7$ & $4 \pm 3.9$ & $1-5$ \\
\hline $\begin{array}{l}\text { Walton } \\
\text { et al [26] }\end{array}$ & Australia & 203 & 15 & FOG-Q item $3 \geq 1$ & $66.77 \pm 8.9$ & $5.1 \pm 5.1$ & $1-3$ \\
\hline $\begin{array}{l}\text { Bohnen } \\
\text { et al [8] }\end{array}$ & $\begin{array}{l}\text { United } \\
\text { States }\end{array}$ & 143 & 14 & $\begin{array}{l}\text { MDS-UPDRS item } \\
3.11 \geq 1\end{array}$ & $65.5 \pm 7.4$ & $6.0 \pm 4.3$ & $2.4 \pm 0.5$ \\
\hline $\begin{array}{l}\text { Ou et al } \\
\text { [27] }\end{array}$ & China & 474 & 16 & FOG-Q item $3 \geq 1$ & $62.09 \pm 10.55$ & $4.77 \pm 4.04$ & $1-5$ \\
\hline $\begin{array}{l}\text { Perez-Lloret } \\
\text { et al [28] }\end{array}$ & French & 672 & 19 & UPDRS item $14 \geq 1$ & $50.7 \%$ patients $\geq 68$ & $50.7 \%$ patients $>5$ & $1-5$ \\
\hline $\begin{array}{l}\text { Auyeung } \\
\text { et al [10] }\end{array}$ & China & 171 & 17 & $\begin{array}{l}\text { sudden and } \\
\text { transient blocks of } \\
\text { movement while } \\
\text { walking }\end{array}$ & $62.2 \pm 10.6$ & All patients $>10$ & $1.5-5$ \\
\hline $\begin{array}{l}\text { Contreras } \\
\text { et al [29] }\end{array}$ & Spain & 160 & 16 & FOG-Q item $3 \geq 1$ & $72.0 \pm 9.5$ & $8.1 \pm 6.4$ & $2.6 \pm 1.0$ \\
\hline $\begin{array}{l}\text { Garcia-Ruiz } \\
\text { et al [30] }\end{array}$ & Spain & 45 & 15 & $\begin{array}{l}\text { sudden and } \\
\text { transient blocks of }\end{array}$ & $58.5 \pm 10.2$ & \multicolumn{2}{|c|}{ a follow-up study of new-onset PD } \\
\hline
\end{tabular}


Table 2 Overview of the studies included in this meta-analysis (Continued)

\begin{tabular}{|c|c|c|c|c|c|c|c|}
\hline Study & Country & $\begin{array}{l}\text { Sample } \\
\text { size }\end{array}$ & $\begin{array}{l}\text { Quality } \\
\text { score }\end{array}$ & $\begin{array}{l}\text { Identification of } \\
\text { FOG }\end{array}$ & Age (years) & Disease duration (years) & $H \& Y$ \\
\hline & & & & $\begin{array}{l}\text { movement while } \\
\text { walking }\end{array}$ & & & \\
\hline $\begin{array}{l}\text { Josiah et al } \\
\text { [31] }\end{array}$ & $\begin{array}{l}\text { United } \\
\text { States }\end{array}$ & 916 & 14 & UPDRS item $14 \geq 1$ & $67.1 \pm 11.0$ & $6.6 \pm 6.0$ & ND \\
\hline $\begin{array}{l}\text { Coelho } \\
\text { et al [32] }\end{array}$ & $\begin{array}{l}\text { Spain } \\
\text { and } \\
\text { Portugal }\end{array}$ & 50 & 15 & ND & $74.1 \pm 7.0$ & $17.9 \pm 6.3$ & $4-5$ \\
\hline $\begin{array}{l}\text { Moore et al } \\
{[9]}\end{array}$ & Israel & 118 & 16 & FOG-Q item $3 \geq 1$ & $65.8 \pm 10.2$ & $8.5 \pm 5.8$ & $2.7 \pm 0.8$ \\
\hline $\begin{array}{l}\text { Giladi et al } \\
{[33,34]}\end{array}$ & $\begin{array}{l}\text { United } \\
\text { States }\end{array}$ & 800 & 15 & UPDRS item $14 \geq 1$ & $61.1 \pm 9.5$ & $2.1 \pm 1.3$ & $1-2$ \\
\hline $\begin{array}{l}\text { Giladi et al } \\
{[33,34]}\end{array}$ & Israel & 172 & 16 & $\begin{array}{l}\text { feet get glued to } \\
\text { the ground was } \\
\text { self-reported }\end{array}$ & $58.3 \pm 13.2$ & $11.8 \pm 5.6$ & $1-5$ \\
\hline
\end{tabular}

H\&Y Hoehn and Yahr staging, FOG-Q freezing of gait questionnaire, UPDRS unified Parkinson's disease rating scale, MDS-UPDRS movement disorder society revised Unified Parkinson's Disease Rating Scale, PD Parkinson's disease, ND no data

${ }^{\text {a }}$ median (q1-q3)

${ }^{b}$ mean (range)

who experienced FOG only during off state, only during on state, and either in on or off states and is independent of dopaminergic response-related symptoms [11, 53]. Nonetheless, if the results of the meta-analysis are to be used as a recommendation for medical decision-making, it is possible to analyze the heterogeneous results of studies [54]. Furthermore, in order to reduce the heterogeneity, the studies without a sufficient description of a random or consecutive design of patient recruitment have already been excluded, and the random-effects model has been used in this meta-analysis to estimate the prevalence of FOG.

\section{Inspiration to surgical work}

Patients with advanced PD often show the axial symptoms, including gait disorders and postural abnormalities [55]. Gait disorders often occur in the situation when the patients' attention shifts or the walking direction changes. At that moment, patients often fall down because the movement of legs lags behind the upper body [56], which has a significant adverse effect on the patients' quality of life [26]. However, the current main treatments of PD patients sometimes do not work in the axial symptoms, including dopamine drug therapy and deep brain stimulation in classical nuclei ( such as subthalamic nucleus and globus pallidus internus) [57]. The pedunculopontine nucleus (PPN) is an important nucleus in the neural activity that controls the initiation of gait. Therefore, it has gained wide attention whether the PPN-DBS could improve the axial symptoms of PD patients [58]. Results in the PD animal model showed that low-frequency PPN-DBS can improve the gait disorders and postural abnormalities [59-61].
More than that, clinical studies have also shown that low-frequency PPN-DBS can selectively improve gait disorders in PD patients [62-64]. In patients with severe freezing of gait and postural abnormalities, which have treated with drugs but not with subthalamic nucleus deep brain stimulation (STN-DBS), deep brain stimulation in the lower and middle parts of the bilateral PPN has shown a good therapeutic effect [65].

In this meta-analysis, we concluded that the overall incidence of freezing of gait was $35.8 \%$. These patients may be suitable for the multi-target DBS because of the insignificant therapeutic effect by dopamine drug therapy and deep brain stimulation in classical nuclei. The therapeutic effect of STN-DBS in the axial symptoms in PD patients remains controversial [66-69]. Some studies suggested that STN-DBS could improve both limb dyskinesia and gait disorders in PD patients [70]. Hamani et al [71] reported that the improvement rate of gait disorders was $64 \%$ at 1 year after STN-DBS. Bejjani et al [72] claimed that gait disorders and postural abnormalities improved at 6 months after STN-DBS. STN-DBS may improve gait disorders and postural abnormalities through the direct stimulation on PPN [70, 73]. In addition, Khan et al [74] reported that PPN-DBS combined with STN-DBS improved the axial symptoms in patients with advanced PD. Although multi-target DBS is still in the clinical exploration stage, it is worthwhile to study how to improve multiple symptoms by stimulating multiple nucleus [75]. Our study showed that the overall incidence of FOG in PD patients was high and was related to the disease duration and severity. Therefore, for PD patients, a detailed assessment of FOG is important for formulating a treatment plan and could not be ignored. 
Table 3 The prevalence of FOG in Parkinson's disease reported in these literatures

\begin{tabular}{|c|c|c|c|c|c|c|}
\hline \multirow[t]{2}{*}{ Study } & \multicolumn{6}{|c|}{ FOG, $\%$ ( $n$ of freezer/n of PD patients) } \\
\hline & In general PD patients & Duration $<5$ years & Duration $\geq 5$ years & Duration $\geq 10$ years & $H \& Y \leq 2.5$ & $H \& Y>2.5$ \\
\hline Margolesky et al [36] & $26.5 \%(27 / 102)$ & & & & & \\
\hline Mckay et al [46] & $40.0 \%(26 / 65)^{c}$ & & & & $33.3 \%(15 / 45)$ & $55.0 \%(11 / 20)$ \\
\hline Mancini et al [40] & $26.6 \%(25 / 94)^{a}$ & & & & & \\
\hline Djaldetti et al [37] & $34.8 \%(15 / 41)$ & & $34.8 \%(15 / 41)$ & & & \\
\hline Ehgoetz Martens et al [38] & $41.6 \%(92 / 221)$ & & & & & \\
\hline Kader et al [44] & $56.8 \%(138 / 243)^{a}$ & & & & & \\
\hline Sutter et al [45] & $41.4 \%(46 / 111)^{\mathrm{a}}$ & & & & $37.0 \%(34 / 92)$ & $63.2 \%(12 / 19)$ \\
\hline Forsyth et al [43] & $39.0 \%(30 / 82)^{a}$ & & & & & \\
\hline Ricciardi et al [41] & $55.8 \%(24 / 43)^{*}$ & & & & & \\
\hline Vervoort et al [42] & $22.4 \%(17 / 76)^{a}$ & & & & & \\
\hline Shin et al [35] & $38.6 \%(54 / 141)$ & $29.2 \%(21 / 73)$ & $48.4 \%(31 / 64)$ & $59.1 \%(13 / 22)$ & & \\
\hline Allen et al [21] & $49.4 \%(114 / 231)$ & & & & & \\
\hline Amboni et al [11] & $54.8 \%(325 / 593)^{a}$ & $27.4 \%(48 / 175)$ & $65.8 \%(271 / 412)$ & $78.3 \%(148 / 189)$ & $35.3 \%(124 / 351)$ & $82.9 \%(194 / 234)$ \\
\hline Forsaa et al [22] & $27.2 \%(63 / 232)^{b}$ & & & $62.5 \%(145 / 232)$ & & \\
\hline Gazibara et al [23] & $36.7 \%(110 / 300)$ & & & & & \\
\hline Lieberman et al [24] & & $12.7 \%(27 / 212)$ & & & & \\
\hline Lindholm et al [25] & $41.1 \%(58 / 141)^{a}$ & & & & & \\
\hline Walton et al [26] & $42.4 \%(86 / 203)^{a}$ & & & & & \\
\hline Bohnen et al [8] & $14.0 \%(20 / 143)$ & & & & & \\
\hline Ou et al [27] & $46.6 \%(221 / 474)^{a}$ & $36.1 \%(108 / 299)$ & $64.6 \%(113 / 175)$ & & $33.5 \%(115 / 343)$ & $82.2 \%(106 / 129)$ \\
\hline Perez-Lloret et al [28] & $38.2 \%(257 / 672)^{b}$ & $25.4 \%(85 / 335)$ & $51.0 \%(172 / 337)$ & & $31.5 \%(174 / 553)$ & $60.0 \%(150 / 250)$ \\
\hline Auyeung et al [10] & & & & $86.5 \%(148 / 171)$ & & \\
\hline Contreras et al [29] & $44.4 \%(71 / 160)^{a}$ & & & & & \\
\hline Garcia-Ruiz et al [30] & & $4.4 \%(2 / 45)$ & $44.4 \%(20 / 45)$ & $68.9 \%(31 / 45)$ & & \\
\hline Josiah et al [31] & $41.5 \%(380 / 916)^{b}$ & & & & & \\
\hline Coelho et al [32] & & & & $62.0 \%(31 / 50)$ & & $62.0 \%(31 / 50)$ \\
\hline Moore et al [9] & $55.1 \%(65 / 118)^{a}$ & & & & & \\
\hline Giladi et al (2001) & & & & & $7.1 \%(57 / 800)$ & \\
\hline Giladi et al (2001) & & & $53.5 \%(92 / 172)$ & & $22.2 \%(10 / 45)$ & $63.8 \%(81 / 127)$ \\
\hline
\end{tabular}

\section{Limitations}

There are a number of limitations in this meta-analysis. First, despite the attempts to identify all suitable publications and to exclude publications stemming from the same database, it is possible that some of the overlapping publications might be missed. Second, although quality criteria were used in all of the papers studied, the inclusion criteria used were subjective to the authors. This may increase the possibility of information bias. Third, the medication state of FOG in most studies was unknown. Therefore, a sub-analysis of the FOG prevalent based on the medication state cannot be performed.
Lastly, the possible influences of pharmacological treatment of FOG cannot be ruled out For example, patients who had FOG but were successfully treated may not be recognized, and this may lead to an underreporting of FOG.

However, taking all of these considerations into account, the overall prevalence rate of FOG in available studies was calculated with the intention to provide a reliable estimation of the rate of FOG in PD patients. Although FOG in PD was relatively neglected for a long time, it has received more attention in the past decade. By demonstrating a high prevalence of FOG in PD 
Table 4 The weighted prevalence of FOG in Parkinson's disease patients and the heterogeneities

\begin{tabular}{|c|c|c|c|c|c|}
\hline Prevalence of FOG & $\begin{array}{l}\text { Number of } \\
\text { studies }\end{array}$ & $\begin{array}{l}\text { Total no. PD } \\
\text { patients }\end{array}$ & $\begin{array}{l}\text { Range of the prevalence } \\
\text { of FOG, } \%\end{array}$ & $\begin{array}{l}\text { Mean prevalence of FOG } \\
(95 \% \mathrm{Cl}), \%\end{array}$ & $\begin{array}{l}\text { Heterogeneity, } \% \\
(P \text { value })\end{array}$ \\
\hline In general PD patients & 22 & 5361 & $14.0-56.8$ & $39.9(35.3-44.5)$ & $91.5 \%(<0.001)$ \\
\hline According to FOG-Q item 3 & 13 & 2559 & $22.4-56.8$ & $43.8(38.5-49.1)$ & $85.9 \%(<0.001)$ \\
\hline According to UPDRS item 14 & 3 & 1820 & $27.2-41.5$ & $36.0(29.0-43.1)$ & $89.1 \%(<0.001)$ \\
\hline According to other criteria & 6 & 982 & $14.0-49.4$ & $34.1(22.8-45.4)$ & $93.3 \%(<0.001)$ \\
\hline \multicolumn{6}{|l|}{$\begin{array}{l}\text { In PD patients with objectively or } \\
\text { subjectively diagnostic criteria }\end{array}$} \\
\hline Objectively & 19 & 4887 & $14.0-56.8$ & $40.2(35.1-45.2)$ & $92.2 \%(<0.001)$ \\
\hline Subjectively & 3 & 474 & $26.5-49.4$ & $38.4(25.2-51.6)$ & $88.8 \%(<0.001)$ \\
\hline \multicolumn{6}{|c|}{$\begin{array}{l}\text { In PD patients with different disease } \\
\text { durations }\end{array}$} \\
\hline$<5$ years & 6 & 1139 & $4.4-36.1$ & $22.4(12.8-31.9)$ & $93.9 \%(<0.001)$ \\
\hline$\geq 5$ years & 7 & 1246 & $34.8-65.8$ & $53.3(45.8-60.8)$ & $84.1 \%(<0.001)$ \\
\hline$\geq 10$ years & 6 & 709 & $59.1-86.5$ & $70.8(60.8-80.9)$ & $88.2 \%(<0.001)$ \\
\hline \multicolumn{6}{|c|}{ In PD patients with different H\&Y stagings } \\
\hline$\leq 2.5$ & 7 & 2229 & 7.1-37.0 & $28.4(15.7-41.1)$ & $97.9 \%(<0.001)$ \\
\hline$>2.5$ & 7 & 829 & $60.0-82.9$ & $68.4(58.7-78.2)$ & $88.4 \%(<0.001)$ \\
\hline
\end{tabular}

FOG-Q freezing of gait questionnaire, UPDRS unified Parkinson's disease rating scale, FOG freezing of gait, $P D$ Parkinson's disease, H\&Y Hoehn and Yahr staging

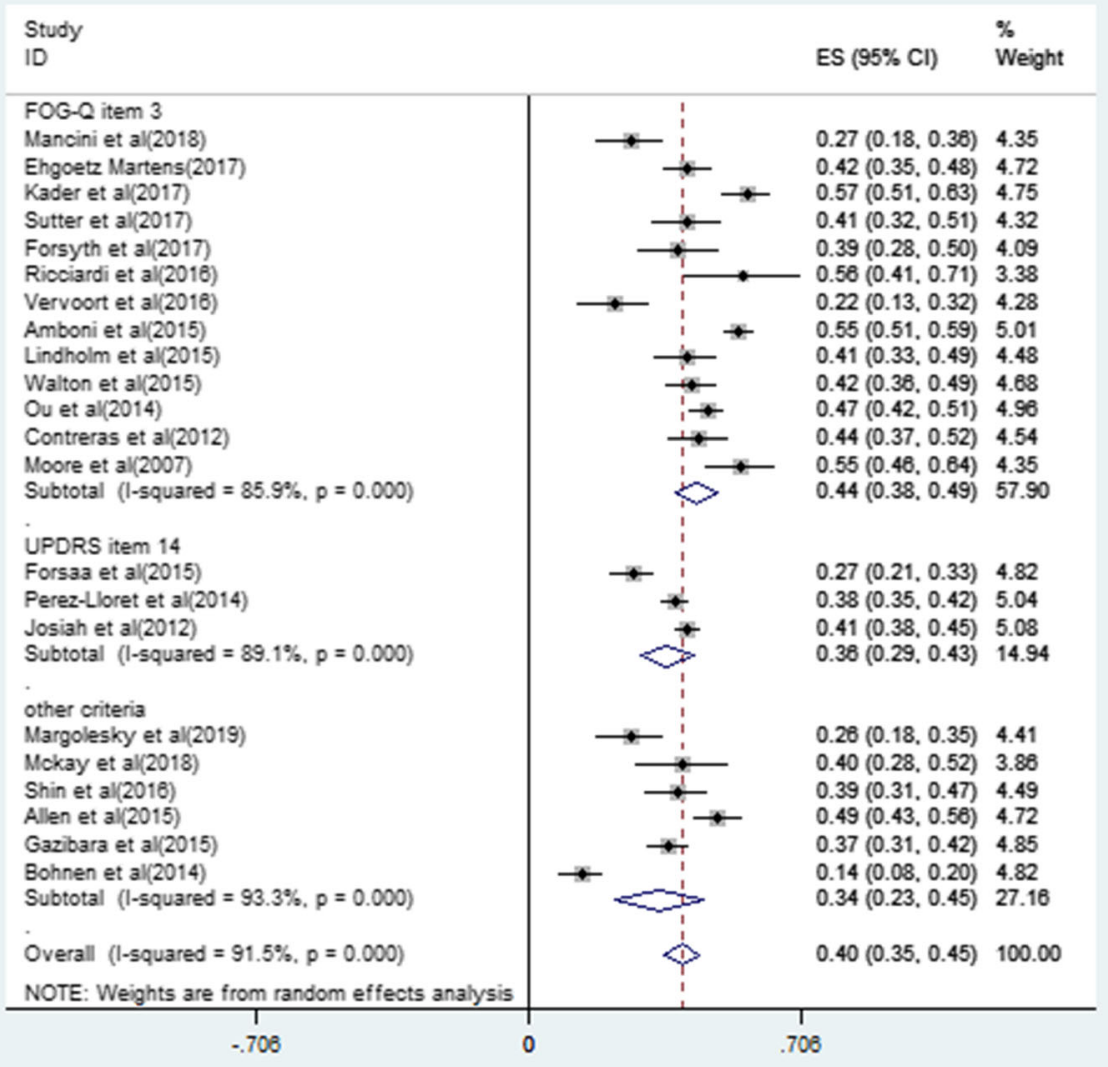

Fig. 2 The prevalence of FOG identified by objectively diagnostic criteria 
Table 5 Sub-group analysis of the FOG prevalence in general PD patients by the quality of included studies, date of study conduction, and geographical region

\begin{tabular}{|c|c|c|c|c|c|}
\hline & Number of studies & Prevalence & $95 \% \mathrm{Cl}$ & $P$ value & Heterogeneity, \% \\
\hline \multicolumn{6}{|l|}{ Quality score } \\
\hline $14-15$ & 8 & $40.0 \%$ & $31.8-48.2 \%$ & $<0.001$ & $92.5 \%$ \\
\hline $16-17$ & 10 & $39.7 \%$ & $32.6-46.8 \%$ & $<0.001$ & $90.1 \%$ \\
\hline 18-19 & 4 & $40.1 \%$ & $28.0-52.3 \%$ & $<0.001$ & $94.5 \%$ \\
\hline \multicolumn{6}{|c|}{ Geographic region } \\
\hline Europe & 9 & $41.7 \%$ & $34.1-49.4 \%$ & $<0.001$ & $93.0 \%$ \\
\hline Asia & 3 & $42.9 \%$ & $28.9-56.8 \%$ & $<0.001$ & $90.7 \%$ \\
\hline United States & 6 & $33.5 \%$ & $22.8-44.2 \%$ & $<0.001$ & $93.4 \%$ \\
\hline Australia & 4 & $43.7 \%$ & $39.4-48.1 \%$ & 0.232 & $30.1 \%$ \\
\hline \multicolumn{6}{|c|}{ Year of study conduction } \\
\hline 2007-2015 & 11 & $40.1 \%$ & $33.6-46.6 \%$ & $<0.001$ & $94.3 \%$ \\
\hline 2016-2019 & 11 & $39.7 \%$ & $32.9-46.6 \%$ & $<0.001$ & $86.0 \%$ \\
\hline
\end{tabular}

FOG freezing of gait, $P D$ Parkinson's disease

(39.9\%), the present meta-analysis highlights the need for accurate identification of FOG in PD.

\section{Conclusions}

This is the first review on the prevalence of FOG in PD. The results showed that the prevalence of FOG in PD is $35.8 \%$ and it varied with different disease durations and severities. It reminded us that physicians should be aware of FOG as a common feature in PD. More accurate diagnostic rating scale and efficient treatments such as multi-target DBS should be further studied and optimized for PD patients to increase their quality of life.

\section{Abbreviations}

FOG: Freezing of gait; PD: Parkinson's disease; H\&Y: Hoehn and Yahr; QUADAS: Assessment of diagnostic accuracy studies; Chi2: Chi-square; FOGQ: Freezing of gait questionnaire; UPDRS: Unified Parkinson's Disease Rating Scale; PPN: Pedunculopontine nucleus; STN: Subthalamic nucleus

\section{Acknowledgements}

This study was supported by the National Natural Science Foundation of China (no.81901395)

\section{Authors' contributions}

H.L.G. and X.Y.C. were major contributors in writing the manuscript. The two authors independently reviewed the full texts of the selected studies. They contributed equally to this work and should be considered co-first authors. Y.X.L., T.J.G., L.H.Y., Z.Y.L., X.Y.W., and D.Z.K. analyzed and interpreted the patient data. C.Y.D. designed the study. All authors read and approved the final manuscript.

\section{Funding}

This study was supported by the National Natural Science Foundation of China (no.81901395). The funding body played an important role in the design of the study.

\section{Availability of data and materials}

All data generated or analyzed during this study are included in the article.

Ethics approval and consent to participate

None
Consent for publication

Not applicable

\section{Competing interests}

The authors declare that they have no competing interests in this section.

\section{Author details}

${ }^{1}$ Department of Neurosurgery, The First Affiliated Hospital of Fujian Medical University, No. 20 Chazhong Road, Fuzhou 350004, Fujian Province, People's Republic of China. 'Brain Center, Quzhou Second People Hospital, Quzhou, People's Republic of China.

Received: 28 September 2019 Accepted: 16 April 2020

Published online: 14 May 2020

\section{References}

1. Nieuwboer A, Giladi N. Characterizing freezing of gait in Parkinson's disease: models of an episodic phenomenon. Mov Disord. 2013;28:1509-19. https:// doi.org/10.1002/mds.25683.

2. Okuma Y. Freezing of gait and falls in Parkinson's disease. J Parkinsons Dis. 2014;4:255-60. https://doi.org/10.3233/JPD-130282.

3. Beck EN, Ehgoetz Martens KA, Almeida QJ. Freezing of gait in Parkinson's disease: an overload problem? PloS One. 2015;10:e0144986. https://doi.org/ 10.1371/journal.pone.0144986.

4. Nutt JG, Bloem BR, Nir G, Mark H, Horak Fay B, Alice N. Freezing of gait: moving forward on a mysterious clinical phenomenon. Lancet Neurol. 2011; 10:734-44. https://doi.org/10.1016/s1474-4422(11)70143-0.

5. Snijders AH, Nijkrake MJ, Bakker M, Munneke M, Wind C, Bloem BR. Clinimetrics of freezing of gait. Mov Disord. 2008;23(Suppl 2):S468-74. https://doi.org/10.1002/mds.22144.

6. Yoon SY, Lee SC, Kim YW. Spatiotemporal characteristics of freezing of gait in patients after hypoxic-ischemic brain injury: a pilot study. Medicine. 2016; 95:e3666. https://doi.org/10.1097/MD.0000000000003666.

7. Jorik N, Snijders Anke H, Nutt John G, Günter D, Nir G, Bloem Bastiaan R. Freezing of gait: a practical approach to management. Lancet Neurol. 2015; 14:768-78. https://doi.org/10.1016/s1474-4422(15)00041-1.

8. Bohnen NI, Frey KA, Studenski S, Kotagal V, Koeppe RA, Constantine GM, et al. Extra-nigral pathological conditions are common in Parkinson's disease with freezing of gait: an in vivo positron emission tomography study. Mov Disord. 2014;29:1118-24. https://doi.org/10.1002/mds.25929.

9. Moore O, Peretz C, Giladi N. Freezing of gait affects quality of life of peoples with Parkinson's disease beyond its relationships with mobility and gait. Mov Disord. 2007;22:2192-5. https://doi.org/10.1002/mds.21659.

10. Auyeung M, Tsoi TH, Mok V, Cheung CM, Lee CN, Li R, et al. Ten year survival and outcomes in a prospective cohort of new onset Chinese 
Parkinson's disease patients. J Neurol Neurosurg Psychiatr. 2012;83:607-11. https://doi.org/10.1136/jnnp-2011-301590.

11. Amboni M, Stocchi F, Abbruzzese G, Morgante L, Onofrj M, Ruggieri S, et al. Prevalence and associated features of self-reported freezing of gait in Parkinson disease: the DEEP FOG study. Parkinsonism Relat Disord. 2015;21: 644-9. https://doi.org/10.1016/j.parkreldis.2015.03.028.

12. Moher D, Liberati A, Tetzlaff J, Altman DG. Preferred reporting items for systematic reviews and meta-analyses: the PRISMA statement. PLoS Med. 2009;6:e1000097. https://doi.org/10.1371/journal.pmed.1000097.

13. Wade R, Corbett M, Eastwood A. Quality assessment of comparative diagnostic accuracy studies: our experience using a modified version of the QUADAS-2 tool. Res Synth Methods. 2013;4:280-6. https://doi.org/10.1002/ jrsm. 1080.

14. Nunes N, Ambler G, Foo X, Naftalin J, Widschwendter M, Jurkovic D. Use of IOTA simple rules for diagnosis of ovarian cancer: meta-analysis. Ultrasound Obstet Gynecol. 2014;44:503-14. https://doi.org/10.1002/uog.13437.

15. Broen MP, Narayen NE, Kuijf ML, Dissanayaka NN, Leentjens AF. Prevalence of anxiety in Parkinson's disease: a systematic review and meta-analysis. Mov Disord. 2016;31:1125-33. https://doi.org/10.1002/mds.26643.

16. Broen MP, Braaksma MM, Patijn J, Weber WE. Prevalence of pain in Parkinson's disease: a systematic review using the modified QUADAS tool. Mov Disord. 2012;27:480-4. https://doi.org/10.1002/mds.24054.

17. Tatjana G, Darija K-T, Marina S, Aleksandra T, Iva S, Kostic Vladimir S, et al. Indoor and outdoor falls in persons with Parkinson's disease after 1 year follow-up study: differences and consequences. Neurol Sci. 2016;37:597-602. https://doi.org/10.1007/s10072-016-2504-2.

18. Guo X, Song W, Chen K, Chen X, Zheng Z, Cao B, et al. Impact of frontal lobe function and behavioral changes on health-related quality of life in patients with Parkinson's disease: a cross-sectional study from Southwest China. Eur Neurol. 2015;74:147-53. https://doi.org/10.1159/000439084.

19. Wu X, Long E, Lin H, Liu Y. Prevalence and epidemiological characteristics of congenital cataract: a systematic review and meta-analysis. Sci Reports. 2016;6:28564. https://doi.org/10.1038/srep28564.

20. Zhang F, Huang Y, Ding C, Huang G, Wang S. The prevalence of hyperprolactinemia in non-functioning pituitary macroadenomas. Int J Clin Exp Med. 2015;8:18990-7.

21. Allen NE, Wong CM, Canning CG, Moloney N. The association between Parkinson's disease motor impairments and pain. Pain Med. 2016;17:456-62. https://doi.org/10.1111/pme.12898.

22. Forsaa EB, Larsen JP, Wentzel-Larsen T, Alves G. A 12-year population-based study of freezing of gait in Parkinson's disease. Parkinsonism Relat Disord. 2015;21:254-8. https://doi.org/10.1016/j.parkreldis.2014.12.020.

23. Gazibara T, Pekmezovic T, Kisic TD, Tomic A, Stankovic I, Kostic VS, et al. Fall frequency and risk factors in patients with Parkinson's disease in Belgrade, Serbia: a cross-sectional study. Geriatr Gerontol Int. 2015;15:472-80. https:// doi.org/10.1111/ggi.12300.

24. Lieberman A, Deep A, Dhall R, Tran A, Liu MJ. Early freezing of gait: atypical versus typical Parkinson disorders. Parkinsons Dis. 2015;2015:951645. https:// doi.org/10.1155/2015/951645.

25. Lindholm B, Hagell P, Hansson O, Nilsson MH. Prediction of falls and/or near falls in people with mild Parkinson's disease. PloS One. 2015;10:e0117018. https://doi.org/10.1371/journal.pone.0117018.

26. Walton CC, Shine JM, Hall JM, O'Callaghan C, Mowszowski L, Gilat M, et al. The major impact of freezing of gait on quality of life in Parkinson's disease. J Neurol. 2015;262:108-15. https://doi.org/10.1007/s00415-014-7524-3.

27. Ou R, Guo X, Song W, Cao B, Yang J, Wei Q, et al. Freezing of gait in Chinese patients with Parkinson disease. J Neurol Sci. 2014;345:56-60. https://doi.org/10.1016/j.jns.2014.07.002.

28. Perez-Lloret S, Negre-Pages L, Damier P, Delval A, Derkinderen P, Destee A, et al. Prevalence, determinants, and effect on quality of life of freezing of gait in Parkinson disease. JAMA Neurol. 2014;71:884-90. https://doi.org/10. 1001/jamaneurol.2014.753.

29. Contreras A, Grandas F. Risk factors for freezing of gait in Parkinson's disease. J Neurol Sci. 2012;320:66-71. https://doi.org/10.1016/j.jns.2012.06.018.

30. Garcia-Ruiz PJ, Del Val J, Fernandez IM, Herranz A. What factors influence motor complications in Parkinson disease?: a 10-year prospective study. Clin Neuropharmacol. 2012;35:1-5. https://doi.org/10.1097/WNF. 0b013e31823dec73.

31. Josiah AF, Gruber-Baldini AL, Anderson KE, Fishman PS, Weiner WJ, Reich SG, et al. The effects of gait impairment with and without freezing of gait in
Parkinson's disease. Parkinsonism Relat Disord. 2012;18:239-42. https://doi. org/10.1016/j.parkreldis.2011.10.008

32. Coelho M, Marti MJ, Tolosa E, Ferreira JJ, Valldeoriola F, Rosa M, et al. Latestage Parkinson's disease: the Barcelona and Lisbon cohort. J Neurol. 2010; 257:1524-32. https://doi.org/10.1007/s00415-010-5566-8.

33. Giladi N, Treves TA, Simon ES, Shabtai H, Orlov Y, Kandinov B, et al. Freezing of gait in patients with advanced Parkinson's disease. J Neural Trans (Vienna, Austria: 1996). 2001;108:53-61. https://doi.org/10.1007/s007020170096.

34. Giladi N, McDermott MP, Fahn S, Przedborski S, Jankovic J, Stern M, et al. Freezing of gait in PD: prospective assessment in the DATATOP cohort. Neurology. 2001;56:1712-21.

35. Shin JY, Pohlig RT, Habermann B. Self-reported symptoms of Parkinson's disease by sex and disease duration. West J Nurs Res. 2017;39:1412-28. https://doi.org/10.1177/0193945916670904.

36. Margolesky J, Bette S, Shpiner DS, Jordan EA, Dong C, Rundek T, et al. Tandem gait abnormality in Parkinson disease: prevalence and implication as a predictor of fall risk. Parkinsonism Relat Disord. 2019. https://doi.org/10. 1016/j.parkreldis.2019.02.034.

37. Djaldetti R, Rigbi A, Greenbaum L, Reiner J, Lorberboym M. Can early dopamine transporter imaging serve as a predictor of Parkinson's disease progression and late motor complications? J Neurol Sci. 2018;390:255-60. https://doi.org/10.1016/j.jns.2018.05.006.

38. Ehgoetz Martens KA, Lukasik EL, Georgiades MJ, Gilat M, Hall JM, Walton CC, et al. Predicting the onset of freezing of gait: a longitudinal study. Mov Disord. 2018;33:128-35. https://doi.org/10.1002/mds.27208.

39. Kim MJ, Oh SB, Kim J, Kim K, Ryu HS, Kim MS, et al. Association of metals with the risk and clinical characteristics of Parkinson's disease. Parkinsonism Relat Disord. 2018;55:117-21. https://doi.org/10.1016/j.parkreldis.2018.05.022.

40. Mancini M, Weiss A, Herman T, Hausdorff JM. Turn Around freezing: community-living turning behavior in people with Parkinson's disease. Front Neurol. 2018;9:18. https://doi.org/10.3389/fneur.2018.00018.

41. Ricciardi L, Ebreo M, Graziosi A, Barbuto M, Sorbera C, Morgante L, et al. Speech and gait in Parkinson's disease: when rhythm matters. Parkinsonism Relat Disord. 2016;32:42-7. https://doi.org/10.1016/j.parkreldis.2016.08.013.

42. Vervoort G, Bengevoord A, Strouwen C, Bekkers EM, Heremans E, Vandenberghe $W$, et al. Progression of postural control and gait deficits in Parkinson's disease and freezing of gait: a longitudinal study. Parkinsonism Relat Disord. 2016;28:73-9. https://doi.org/10.1016/.jparkreldis.2016.04.029.

43. Forsyth AL, Paul SS, Allen NE, Sherrington C, Fung VS, Canning CG. Flexed truncal posture in Parkinson disease: measurement reliability and relationship with physical and cognitive impairments, mobility, and balance. J Neurol Phys Therapy. 2017;41:107-13. https://doi.org/10.1097/NPT. 0000000000000171

44. Kader M, Ullen S, Iwarsson S, Odin P, Nilsson MH. Factors contributing to perceived walking difficulties in people with Parkinson's disease. J Parkinsons Dis. 2017;7:397-407. https://doi.org/10.3233/JPD-161034.

45. Sutter EN, Seidler K, Duncan RP, Earhart GM, McNeely ME. Low to moderate relationships between gait and postural responses in Parkinson disease. J Rehabil Med. 2017:49:505-11. https://doi.org/10.2340/16501977-2238.

46. Lucas MK, Lang Kimberly C, Ting Lena H, Hackney Madeleine E. Impaired set shifting is associated with previous falls in individuals with and without Parkinson's disease. Gait Posture. 2018;62:220-6 10.1016/j.gaitpost.2018.02.027.

47. Giladi N, Tal J, Azulay T, Rascol O, Brooks DJ, Melamed E, et al. Validation of the freezing of gait questionnaire in patients with Parkinson's disease. Mov Disord. 2009;24:655-61. https://doi.org/10.1002/mds.21745.

48. Hiorth Y. H., Larsen J. P., Lode K., Pedersen K. F. Natural history of falls in a population-based cohort of patients with Parkinson's disease: an 8-year prospective study. Parkinsonism Relat Disord.0 2014;20:1059-1064.doi:https:// doi.org/10.1016/j.parkreldis.2014.06.023.

49. Baggio JA, Curtarelli MB, Rodrigues GR, Tumas V. Validation of the Brazilian version of the clinical gait and balance scale and comparison with the Berg balance scale. Arquivos de neuro-psiquiatria. 2013;71:621-6. https://doi.org/ 10.1590/0004-282X20130107.

50. Duncan RP, Earhart GM. Measuring participation in individuals with Parkinson disease: relationships with disease severity, quality of life, and mobility. Disab Rehabil. 2011;33:1440-6. https://doi.org/10.3109/09638288. 2010.533245.

51. Zhang H, Yin X, Ouyang Z, Chen J, Zhou S, Zhang C, et al. A prospective study of freezing of gait with early Parkinson disease in Chinese patients. Medicine. 2016;95:e4056. https://doi.org/10.1097/MD.0000000000004056. 
52. Ghafari M, Baigi V, Cheraghi Z, Doosti-Irani A. The prevalence of asymptomatic bacteriuria in Iranian pregnant women: a systematic review and meta-analysis. PloS One. 2016;11:e0158031. https://doi.org/10.1371/ journal.pone.0158031.

53. Espay AJ, Fasano A, van Nuenen BF, Payne MM, Snijders AH, Bloem BR. "On" state freezing of gait in Parkinson disease: a paradoxical levodopa-induced complication. Neurology. 2012;78:454-7. https://doi.org/10.1212/WNL. 0b013e3182477ec0.

54. Poole C, Greenland S. Random-effects meta-analyses are not always conservative. Am J Epidemiol. 1999;150:469-75.

55. Fasano A, Aquino CC, Krauss JK, Honey CR, Bloem BR. Axial disability and deep brain stimulation in patients with Parkinson disease. Nat Rev Neurol. 2015;11:98-110. https://doi.org/10.1038/nrneurol.2014.252.

56. Canning CG, Paul SS, Nieuwboer A. Prevention of falls in Parkinson's disease: a review of fall risk factors and the role of physical interventions. Neurodegener Dis Manag. 2014:4:203-21. https://doi.org/10.2217/nmt.14.22.

57. Ferraye MU, Debu B, Pollak P. Deep brain stimulation effect on freezing of gait. Mov Disord. 2008;23(Suppl 2):S489-94. https://doi.org/10.1002/mds.21975.

58. Vingerhoets FJ, Tagliati M. Treating PD axial signs with DBS: is two better than one? Neurology. 2012;78:1036-7. https://doi.org/10.1212/WNL. Ob013e31824e8fd4.

59. Wen P, Li M, Xiao H, Ding R, Chen H, Chang J, et al. Low-frequency stimulation of the pedunculopontine nucleus affects gait and the neurotransmitter level in the ventrolateral thalamic nucleus in 6-OHDA Parkinsonian rats. Neurosci Lett. 2015;600:62-8. https://doi.org/10.1016/j. neulet.2015.06.006.

60. Park E, Song I, Jang DP, Kim IY. The effect of low frequency stimulation of the pedunculopontine tegmental nucleus on basal ganglia in a rat model of Parkinson's disease. Neurosci Lett. 2014;577:16-21. https://doi.org/10. 1016/j.neulet.2014.05.062.

61. Jenkinson N, Nandi D, Oram R, Stein JF, Aziz TZ. Pedunculopontine nucleus electric stimulation alleviates akinesia independently of dopaminergic mechanisms. Neuroreport. 2006;17:639-41. https://doi.org/10.1097/ 00001756-200604240-00016.

62. Ferraye MU, Debu B, Fraix V, Goetz L, Ardouin C, Yelnik J, et al. Effects of pedunculopontine nucleus area stimulation on gait disorders in Parkinson's disease. Brain. 2010;133:205-14. https://doi.org/10.1093/brain/awp229.

63. Moro E, Hamani C, Poon YY, Al-Khairallah T, Dostrovsky JO, Hutchison WD, et al. Unilateral pedunculopontine stimulation improves falls in Parkinson's disease. Brain. 2010;133:215-24. https://doi.org/10.1093/brain/awp261.

64. Stefani A, Lozano AM, Peppe A, Stanzione P, Galati S, Tropepi D, et al. Bilateral deep brain stimulation of the pedunculopontine and subthalamic nuclei in severe Parkinson's disease. Brain. 2007;130:1596-607. https://doi. org/10.1093/brain/awl346.

65. Thevathasan W, Coyne TJ, Hyam JA, Kerr G, Jenkinson N, Aziz TZ, et al. Pedunculopontine nucleus stimulation improves gait freezing in Parkinson disease. Neurosurgery. 2011;69:1248-53; discussion 54. https://doi.org/10. 1227/NEU.0b013e31822b6f71.

66. Sidiropoulos C. Low-frequency stimulation of STN-DBS reduces aspiration and freezing of gait in patients with PD. Neurology. 2015;85:557. https://doi. org/10.1212/WNL.0000000000001823.

67. Vercruysse S, Vandenberghe W, Munks L, Nuttin B, Devos H, Nieuwboer A. Effects of deep brain stimulation of the subthalamic nucleus on freezing of gait in Parkinson's disease: a prospective controlled study. J Neurol Neurosurg Psychiatry. 2014;85:871-7. https://doi.org/10.1136/jnnp-2013306336.

68. Fling BW, Cohen RG, Mancini M, Carpenter SD, Fair DA, Nutt JG, et al. Functional reorganization of the locomotor network in Parkinson patients with freezing of gait. PLoS One. 2014;9:e100291. https://doi.org/10.1371/ journal.pone.0100291.

69. Johnsen EL, Sunde N, Mogensen PH, Ostergaard K, Ostergaard K. MRI verified STN stimulation site--gait improvement and clinical outcome. Eur J Neurol. 2010;17:746-53. https://doi.org/10.1111/j.1468-1331.2010.02962.x.

70. Potter-Nerger M, Volkmann J. Deep brain stimulation for gait and postural symptoms in Parkinson's disease. Mov Disord. 2013;28:1609-15. https://doi. org/10.1002/mds.25677.

71. Hamani C, Richter E, Schwalb JM, Lozano AM. Bilateral subthalamic nucleus stimulation for Parkinson's disease: a systematic review of the clinical literature. Neurosurgery. 2005;56:1313-21. https://doi.org/10.1227/01.neu. $0000159714.28232 . c 4$
72. Bejjani BP, Gervais D, Arnulf I, Papadopoulos S, Demeret S, Bonnet AM, Cornu P, et al. Axial parkinsonian symptoms can be improved: the role of levodopa and bilateral subthalamic stimulation. J Neurol Neurosurg Psychiatry. 2000;68:595-600. https://doi.org/10.1136/jnnp.68.5.595.

73. Guehl D, Dehail P, de Seze MP, Cuny E, Faux P, Tison F, et al. Evolution of postural stability after subthalamic nucleus stimulation in Parkinson's disease: a combined clinical and posturometric study. Exp Brain Res. 2006; 170:206-15. https://doi.org/10.1007/s00221-005-0202-z.

74. Khan S, Gill SS, Mooney L, White P, Whone A, Brooks DJ, et al. Combined pedunculopontine-subthalamic stimulation in Parkinson disease. Neurology. 2012:78:1090-5. https://doi.org/10.1212/WNL.0b013e31824e8e96.

75. Johnson L, Rodrigues J, Teo WP, Walters S, Stell R, Thickbroom G, et al. Interactive effects of GPI stimulation and levodopa on postural control in Parkinson's disease. Gait Posture. 2015;41:929-34. https://doi.org/10.1016/j. gaitpost.2015.03.346
Ready to submit your research? Choose BMC and benefit from:

- fast, convenient online submission

- thorough peer review by experienced researchers in your field

- rapid publication on acceptance

- support for research data, including large and complex data types

- gold Open Access which fosters wider collaboration and increased citations

- maximum visibility for your research: over $100 \mathrm{M}$ website views per year

At $\mathrm{BMC}$, research is always in progress.

Learn more biomedcentral.com/submissions 